\title{
A 26-year-old female with faulty existing restorations
}

\author{
Ram Udgar Yadav, Sageer Ahmed and Mozammal Hossain
}

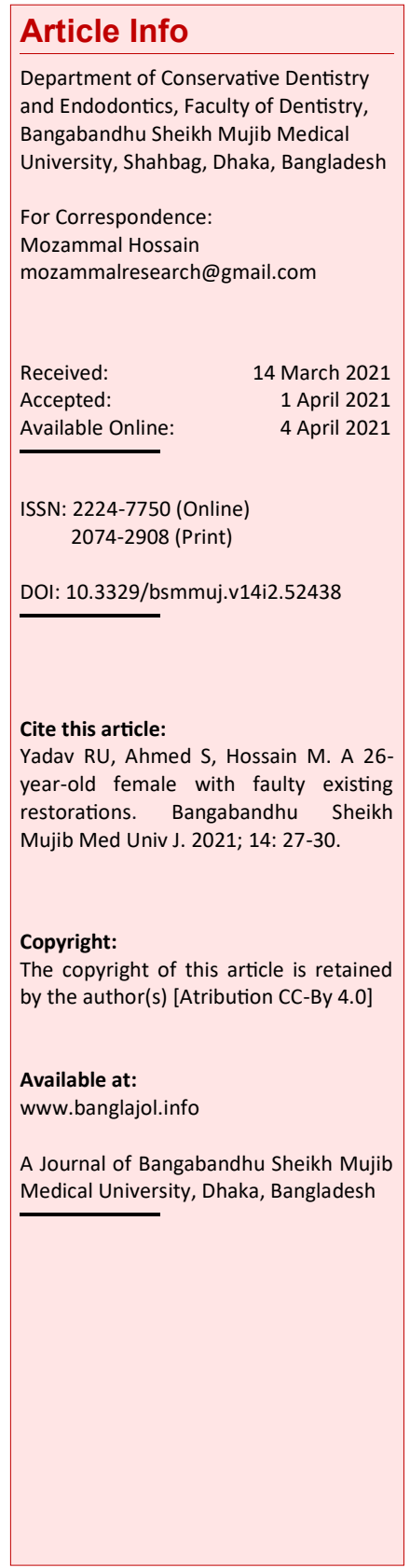

Dental fluorosis

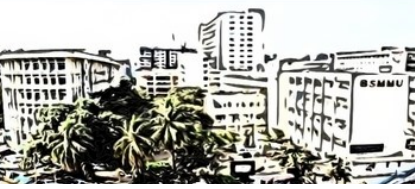

\section{Presentation of Case}

Dr. Ram Udgar Yadav (MS Resident): A 26-yearold female came with unaesthetic restorations on the upper four anterior teeth. She gave a history of the restoration of the teeth 6 months ago that underwent progressive marginal discoloration. On clinical examination, two upper central and two lateral incisor teeth were restored by Glass Ionomer cement and Secondary caries were present beneath restorations (Figure 1-A). Teeth were vital and did not respond to percussion and mobility test.

Dr. Yadav: Radiographic examination revealed that the four maxillary anterior teeth $(2$ central and 2 laterals) had the existing restoration which showed a radioopaque area in the proximal surface but radiolucent areas were also seen beneath the radioopaque area that extends to the dentin. However, there was no involvement of the pulp and periodontal tissues.

\section{Provisional Diagnosis}

Marginal discoloration of existing restorations

\section{Differential Diagnosis}

\section{Pulp necrosis}

Dr. Sageer Ahmed (MS Resident): Pulp necrosis is found without any painful symptoms. $\underline{1,2}$ Discoloration of the tooth is the first symptom of pulp death. $.3,4$ In some cases, the patient may give the history of severe pain which last for a few min to hours and then it stops with sudden and complete cessation of pain. $.5,6$ It progresses slowly and silently, but the patient is unaware of symptoms.? Radiograph shows no change of periapical tissue. As such signs and symptoms were absent in the present case, it was excluded from the diagnosis.

Dr Ahmed: Dental fluorosis mainly occurs on both sides and presents with a white band across the tooth surface. $\frac{8,9}{2}$ The lesion can be seen to a few teeth or can include the full dentition. The lesions are present in the enamel and can vary from deep to superficial based on the severity of the fluorosis. The patient may give a history of prolonged exposure to fluoride intake. Since chalky white doesn't appear on the overall tooth surface and there was no history of fluoride exposure, it was excluded from the diagnosis.

\section{Rampant caries}

Dr. Ahmed: Rampant caries is characterized by severe involvement of all the permanent teeth except the mandibular incisor and mandibular canine.10,11 It is usually present in the adolescent age group and gives history of excess sugar intake. Poor oral hygiene is also present. Since there was the involvement of only maxillary incisors and therefore, it was excluded from the diagnosis.

\section{Dr. Yadav's Diagnosis}

Secondary caries

\section{Treatment Procedure}

Dr. Yadav: The affected teeth were planned to restore with composite by layering technique. Alginate impressions of maxillary and Mandibular arches were made, to make casts. Shade selection was performed first by placing composite buttons (Figure 1-B). The enamel and Dentine shades selected were A1 and A2 respectively. Thereafter, oral prophylaxis was performed. A rubber dam was placed and floss was tied to complete isolation and expose Cavo -surface gingival margins. Existing restorations were completely removed. Natural teeth were preserved as much as possible (Figure 1-C). Beveling of margins was done with red-coded fissure bur. A Teflon strip was placed on an adjacent tooth structure. Tooth \#11, \#12, \#21, \#22 was etched for 15 seconds with 37\% Phosphoric acid. The etchant was removed by spraying water for 30 seconds. Silicon index was made with Addition silicon. A 7th generation adhesive system was placed in the cavity and beveled margins. It was air thinned and polymerized for 20 seconds. With the help 

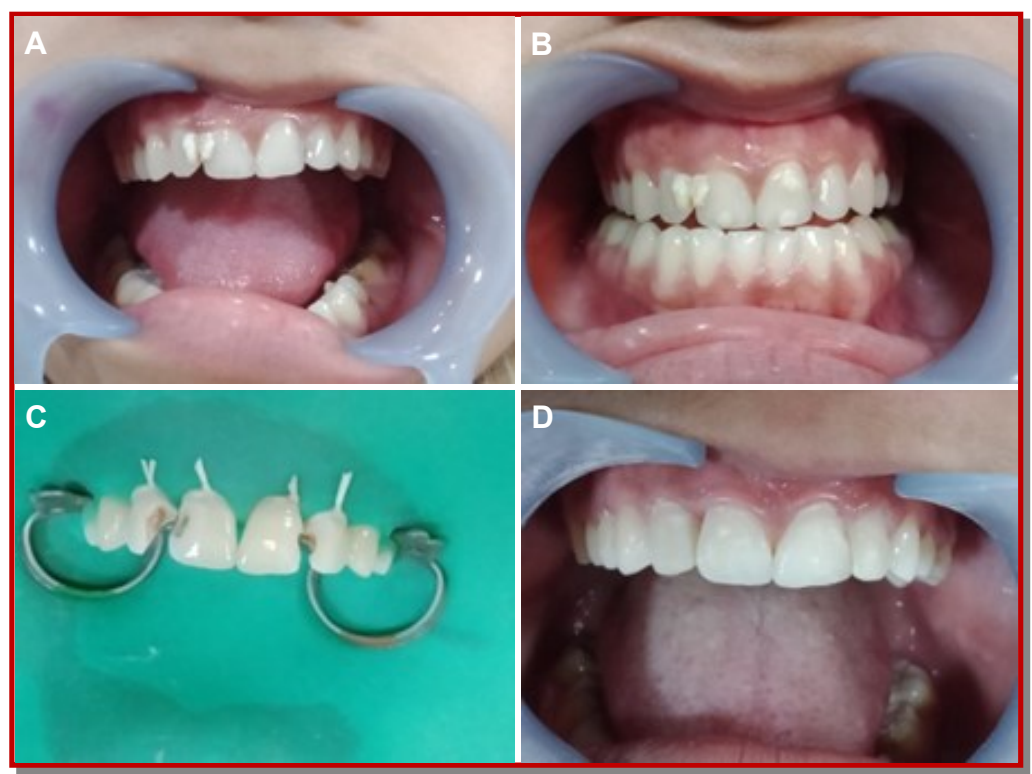

Figure 1. The preoperative view showed existing restorations in maxillary incisor teeth which are considered to be esthetically unpleasant (A); shade selection was performed by placing the composite buttons on the labial surface of the teeth (B), a rubber dam isolation was performed to keep the surface dry and avoid moisture contamination (C); final restoration showed excellent color match and marginal adaptation (D)

of silicon index, a lost palatal wall was built on tooth \#11, \#12, \#21, and \#22. Enamel shade was used here. Then, the proximal wall was built with the help of a sectional matrix using enamel shade. Dentine layer (A2) composite was used in the cervical area and middle third area in wedgeshaped increments and light-cured each increment. An enamel layer was then applied as the final layer on the facial surface and light-cured. Final curing was done under glycerin. The patient was recalled after 24 hours and finishing was started. Gross finishing was done with red-coded fissure diamond bur along with a coarse disc (3M, USA). Prepolishing with the help of a rubber cup and magic mix (Bioclear, USA). Final polishing was done with a Rockstar polisher (Figure 1-D).

\section{Discussion}

\section{Regarding restoration technique}

Direct composite restoration has good clinical performance, and its use in the clinic should be performed according to the treatment plan as mentioned in different literature. 12,13 Type of composite resin, methods, and the operative procedure (beveling of enamel margin, rubber dam application) should be considered for the success and longevity of this treatment. $.14,15$ Therefore, special care should be taken in direct composite restoration. Moreover, the size and form of the maxillary anterior teeth are also important to establish facial esthetics and favorable occlusion. $\frac{16,17}{17}$ To achieve a good esthetic and contour, casts restoration with occlusal guides, as well as diagnostic wax is recommended by some of the previous studies. Silicon or alginate impression is favorable to prepare a cast because it can transfer anatomical details of shape and texture present in the wax and creating a shelf on which composite can be layered in a controlled manner. $\underline{18,19}$

It will not only facilitate the operative procedure but also improve the properties of composite resin. Moreover, the planning of the work and using silicon index leads to fewer errors. This ensures greater predictability of the case and can add security to professionals and patients regarding treatment. Therefore, in the present case, the cast restoration technique was performed to increase the longevity for restoration.

\section{Regarding restoration material}

Many previous studies have confirmed a high success rate for direct restorations with composite resin; 95\% success rate for restorations of class III and 90\% for Class IV restorations after 10 years have been observed.20,21 To improve its success rate, nanohybrid composites have been developed by using nanoparticles and pre-polymerized resin fillers, similar to those found in the microfill composites, and have named this group "nanohybrids.22,23 It is also supplied in a variety of different colors and considered as a better esthetic restoration. Furthermore, due to its higher strength and polishability, its use in anterior and posterior applications has been expected. 24,25

Other factors are associated with achieving natural aesthetics. Among them, the choice of material with good optical properties, mixing of colors of composite plays an important role. However, it is often difficult to reproducing dental tissues naturally because dentin has a chromatic translucency, and its saturation increasing over time. $\underline{26,27}$ On the other hand, enamel present with either chromatic or achromatic translucency. $\frac{28,29}{2}$ Furthermore, as the enamel and dentin composite resin have different compositions, the choice of material and pigment is very important, and the color perception of the dentin composite resin is determined by the enamel composite resin selected. $.30,31$

It is also important to repair the existing restoration other than replacement. The repair of composite resin has been investigated in formal studies.32-34 $\mathrm{A}$ study showed that the performance of repaired restorations was similar to restorations that have been replaced, over the 10 to 12 years which is originally based on the marginal adaptation, secondary caries, and anatomy. $.33,34$ When clinically indicated, repair of the composite should be the treatment of choice. In this case, existing restorations were replaced due to marginal discoloration, lack of color similarity, and improper marginal adaptation. 


\section{Final Diagnosis}

Secondary caries due to defective restoration

\section{Follow-up}

When the patient was called after 7 days following completion of treatment, the restoration margin was intact and there was no increase in the size of the lesion.

Dr. Sah (MS Student): What are methods that we can adopt to increase longevity in such aesthetic restorations?

Dr. Yadav: Proper excavation of caries, good isolation to prevent micro-leakage, marginal finishing of the cavity, proper condensation, adequate curing, polishing of restoration at regular intervals, and patient motivation to maintain oral hygiene are important factors for increasing longevity of such restoration.

Dr. Ahmed: What is an alternative technique to the traditional rubber dam?

Dr. Yadav: Handi dam, insti dam, optra dam, isolite are the alternatives to traditional rubber dam.

\section{Conflict of Interest}

Authors declare no conflict of interest

\section{References}

1. Dummer PM, Hicks R, Huws D. Clinical signs and symptoms in pulp disease. Int Endod J. 1980; 13: 27 35.

2. Chueh LH, Ho YC, Kuo TC, Lai WH, Chen YH, Chiang CP. Regenerative endodontic treatment for necrotic immature permanent teeth. J Endod. 2009; 35: $160-64$.

3. Andreasen FM, Kahler B. Pulpal response after acute dental injury in the permanent dentition: Clinical implications. J Endod. 2015; 41: 299-308.

4. Marin PD, Bartold PM, Heithersay GS. Tooth discoloration by blood: An in vitro histochemical study. Dent Traumatol. 1997; 13: 132-38.

5. Watts AM, Addy M. Tooth discolouration and staining: A review of the literature. Br Dent J. 2001; 190: 309-16.

6. Hahn CL, Liewehr FR. Innate immune responses of the dental pulp to caries. J Endod. 2007; 33: 643-51.

7. Ali SG, Mulay S. Pulpitis: A review. Int Dent Med Sci. 2015; 14: 92-97.

8. Mascarenhas AK. Risk factors for dental fluorosis: A review of the recent literature. Pediatr Dent. 2000; 22: 269-77.

9. Fomon SJ, Ekstrand J, Ziegler EE. Fluoride intake and prevalence of dental fluorosis: Trends in fluoride intake with special attention to infants. J Public Health Dent. 2000; 60: 131-39.

10. Ayhan H, Suskan E, Yildirim S. The effect of nursing or rampant caries on height, body weight and head circumference. J Clin Pediatr Dent. 1996; 20: 209-12.

11. Johnston T, Messer LB. Nursing caries: literature review and report of a case managed under local anaesthesia. Aus Dent J. 1994; 39: 373-81.

12. Pontons-Melo JC, Furuse AY, Mondelli J (2011) A direct composite resin stratification technique for restoration of the smile. Quintessence Int. 2011; 42: 205-11.

13. Humel MM, Takahashi JM, Paulillo LA, Mesquita MF, Martins LR. Direct restorative treatment of anterior weared teeth after re-establishment of occlusal vertical dimension: A case report. Gerodontology 2012; 29: 299-307.

14. Moraschini V, Fai CK, Alto RM, Dos Santos GO. Amalgam and resin composite longevity of posterior restorations: A systematic review and metaanalysis. J Dent. 2015; 43: 1043-50.

15. Opdam NJ, Bronkhorst EM, Loomans BA, Huysmans MC. Longevity of repaired restorations: A practice based study. J Dent. 2012; 40: 829-35.

16. Garcia AR, Sundfeld RH, de Alexandre RS. Reestablishment of occlusion with prosthesis and composite resin restorations. Bulletin Tokyo Dent Colleg. 2009; 50: 91-96.

17. Deliperi S, Bardwell DN. Multiple cuspal-coverage direct composite restorations: Functional and esthetic guidelines. J Esthet Restorativ Dent. 2008; 20: 300 -08 .

18. Gordan VV, Garvan CW, Blaser PK, Mondragon E, Mjör IA. A long-term evaluation of alternative treatments to replacement of resin-based composite restorations: Results of a seven-year study. J Am Dent Assoc. 2009; 140: 1476-84.

19. Shibata S, Taguchi C, Gondo R, Stolf SC, Baratieri LN. Ceramic veneers and direct-composite cases of Amelogenesis imperfecta rehabilitation. Oper Dent. 2015; 41: 233-42. 
20. Heintze SD, Rousson V, Hickel R. Clinical effectiveness of direct anterior restorations: A meta-analysis. Dent Mater. 2015; 31: 481-95.

21. Demarco FF, Collares K, Coelho-de-Souza FH, Correa MB, Cenci MS, Moraes RR, Opdam NJ. Anterior composite restorations: A systematic review on long-term survival and reasons for failure. Dent Mater. 2015; 31: 1214-24.

22. Ali H, Hossain M, Abdin MJ. A 42-year-old female with thermal sensitivity in the lower left first molar tooth. Bangabandhu Sheikh Mujib Med Univ J. 2018; 11: 231-35.

23. Tabassum ST, Hossain M, Gafur MA, Ali H, Abdin MI, Moral MAA. Wear of nanohybrid and microfilled composite resin in occlusal restoration of first permanent molar tooth. Bangabandhu Sheikh Mujib Med Univ J. 2019; 12: 133-37.

24. St Germain H, Samuelson BA. Surface characteristics of resin composite materials after finishing and polishing. Gener Dent. 2015; 63: 26-32.

25. Sonwane SR, Hambire UV. Comparison of flexural and compressive strengths of nano hybrid composites. Inter J Engin Trends App. 2015; 2: 47-52.

26. Villarroel M, Fahl N, De Sousa AM, de Oliveira OB. Direct esthetic restorations based on translucency and opacity of composite resins. J Esthet Restorativ Dent. 2011; 23: 73-87.

27. Dietschi D, Ardu S, Krejci I. A new shading concept based on natural tooth color applied to direct composite restorations. Quint Int. 2006; 37: 91-102.

28. Terry DA, Geller W, Tric O, Anderson MJ, Tourville $\mathrm{M}$, et al. Anatomical form defines color: Function, form, and aesthetics. Pract Proced Aesthet Dent. 2002; 14: 59-67.

29. Mayoral JR, Arocha MA, Domínguez S. In vivo spectrophotometric evaluation of pure enamel and enamel-dentine complex in relationship with different age groups. J Dent. 2013. 41: 1245-50.

30. Villarroel M, Fahl N, De Sousa AM, De Oliveira OB. Direct esthetic restorations based on translucency and opacity of composite resins. J Esthet Restor Dent. 2011; 23: 73-88.

31. Vichi A, Louca C, Corciolani G, Ferrari M. Color related to ceramic and zirconia restorations: A review. Dent mater. 2011; 27: 97-108.

32. Fernández E, Martín J, Vildósola P, Oliveira Junior $\mathrm{OB}$, Gordan V. Can repair increase the longevity of composite resins?: Results of a 10-year clinical trial. J Dent 2015; 43: 279-86.

33. Hickel R, Brüshaver K, Ilie N. Repair of restorations -criteria for decision making and clinical recommendations. Dent Mater. 2013; 29: 28-50.

34. Estay J, Martín J, Viera V, Valdivieso J, Bersezio C, Vildosola P, Mjor IA, Andrade MF, Moraes RR, Moncada G, Gordan VV. 12 years of repair of amalgam and composite resins: A clinical study. Oper Dent. 2018; 43: 12-21. 